\title{
Heavy Metal Analysis On Blush On Online Selling by Atomic Absorption Spectrophotometry Method (AAS)
}

\author{
Diana Sylvia ${ }^{1, *}$ Dini Lanjar Sari ${ }^{2,}$ Nita Rusdiana ${ }^{3}$ \\ 1,2,3 Departement of Pharmacy, Muhammadiyah Tangerang College of Pharmacy \\ *Corresponding Author. Email: didisylvia817@gmail.com
}

\begin{abstract}
Cosmetics are a daily human need. The number of cosmetics on the market is thought to contain hazardous or toxic substances, one of which is heavy metals. Based on BPOM RI Regulation Number Hk.03.1.23.07.11.6662 Year 2011 Regarding the requirements for heavy metals in cosmetics, the very limit for $\mathrm{Pb}$ heavy metal contamination in cosmetics should not be more than $20 \mathrm{mg} / \mathrm{kg}$ and $\mathrm{Cd}$ should not be more than $5 \mathrm{mg} / \mathrm{kg}$. Analysis of $\mathrm{Pb}, \mathrm{Cd}$ and $\mathrm{Cr}$ metals in blush preparations that have a registration number and do not have a BPOM registration number purchased online in Tangerang City using the atomic absorption spectrophotometric method. This study aims to determine the levels of heavy metals $\mathrm{Pb}, \mathrm{Cd}$ and $\mathrm{Cr}$ in each sample. The sample of blush on which was studied was 5 samples. The results showed that, the blush samples analyzed using the Atomic Absorption Spectrophotometry method did not contain heavy metals such as $\mathrm{Pb}, \mathrm{Cd}$, only one sample of the $\mathrm{VV}$ brand was read as containing $\mathrm{Cr}$ metal. In the sample of the VV brand it was detected that it contained $\mathrm{Cr}$ metal with a level of $1.80 \mathrm{mg} / \mathrm{kg}$, the metal content was still on the threshold referring to (Nigeria $9.81 \mu \mathrm{g} / \mathrm{g}$ and USA $15.09 \mu \mathrm{g} / \mathrm{g}$ ).
\end{abstract}

Keywords: Atomic Absorption Spectrophotometry, Blush On, Heavy metals.

\section{INTRODUCTION}

Cosmetics nowadays have become one of the daily necessities that cannot be separated from human life. Not only women, even men are currently using cosmetics. Cosmetics themselves are basically the base that are used on the body to clean and improve their appearance (Djamilah, 2018). There are more and more cosmetic products nowadays, one of which is blush or cheek coloring. Blush is a cosmetic preparation that is used to color the cheeks with an artistic touch so that it can increase the fresh impression in make-up (Kusantati, 2008: 126). The colors displayed in the blush on are very diverse, now many new color variations have been presented to provide different color nuances. The existence of these different colors, one of which can be caused by the addition of color pigments containing heavy metals or dangerous metals.

Heavy metals that are intentionally added as dyes are basically possible or allowed, but there are limitations. Each country has rules, including in Indonesia. According to the Regulation of the Head of the Drug and Food Control Agency of the Republic of Indonesia Number 17 of 2014 concerning Amendments to the Regulation of the Head of the Drug and Food Supervisory Agency Number HK.03.1.23.07.11.6662 of 2011 concerning Requirements for Microbial Contamination and Heavy Metal in Cosmetics, the limitation of the heavy metal Lead $(\mathrm{Pb})$ and Cadmium $(\mathrm{Cd})$ of $<20 \mathrm{mg}$ $/ \mathrm{kg}$ and $<5 \mathrm{mg} / \mathrm{kg}$, respectively. (Batistad al., 2016).

Based on several studies that have been conducted, there are still found heavy metal content that exceeds the limit set by BPOM. One of the advantages contained in this cosmetic is the various color variations, resulting from the addition of pigments that can come from minerals, organic or metal compounds, such as $\mathrm{Cd}, \mathrm{Co}, \mathrm{Cr}, \mathrm{Cu}, \mathrm{Ni}$ and $\mathrm{Pb}$ as impurities in pigment formulations (Valet et al. ., 2007; Volpedkk.,
2012; Barros et al., 2015). Generally, the use of cosmetic products is applied directly to the skin, therefore these cosmetics can pose health risks and may allow skin reactions such as excessive sensitivity and irritation (Forte et al., 2008).

According to research conducted by Jaya et al., 2013; Ardyanto 2005 said that the potential source of heavy metal contamination could come from the heavy metal compounds themselves, for example lead compounds as dyes or pigments, in the form of $\mathrm{Pb}$ carbonate and $\mathrm{Pb}$ sulfate. Another potential source comes from the instruments / equipment used in the production process (Hepp et al., 2009). The New York Department of Health (1999) states that lead is harmful to adults, children and infants, its impact can affect the development of the brain and nervous system. Widowati in 2008, stated that lead methoxicity is classified based on the organ that it affects, for example in the cardiovascular system, $\mathrm{Pb}$ accumulation causes an increase in blood vessel premeability. On the other hand, consumption of low levels of $\mathrm{Cd}$ for a long period of time can lead to metal buildup in the kidneys with possible damage. Exposure to low levels of $\mathrm{Cd}$ can also cause bones to become brittle and break easily (Bocca et al., 2014).

Research related to this research is according to Andayani's research ( 2018 ), "Analysis of Metal Chromium (Cr) in Blush On ) In atomic absorption spectrophotometry". This study showed that the samples of blusher brands IZ, VV, $\mathrm{KS}, \mathrm{MC}$ were detected to contain chromium metal with levels of $10.05 \pm 0.05 \mu \mathrm{g} / \mathrm{g}$, respectively; $6.74 \pm 0.02 \mu \mathrm{g} / \mathrm{g} ; 28.95 \pm$ $0.19 \mu \mathrm{g} / \mathrm{g} ; 13.52 \pm 0.63 \mu \mathrm{g} / \mathrm{g}$. The data indicate that chromium is present in all samples. Based on this background, on this research will be carried out a quantitative analysis of heavy metal contamination of $\mathrm{Pb}, \mathrm{Cd}$ and $\mathrm{Cr}$ in the blush on sample Atomic Absorption Spectrophotometer (AAS). 


\section{RESEARCH METHODS}

The type of this research is a laboratory experimental, which is to determine the presence of heavy metals in blush on that are sold online in Tangerang City by using the Atomic Absorption Spectrophotometric Method (AAS).

\subsection{Tools}

The tools that were used in this research were Agilent Series 200 AA Atomic Absorption Spectrophotometry (AAS), analytical balance ,volume pipette, micropipette , digestion tube, volumetric flask, glass bottle, filter paper Whatman No.40.

\subsection{Materials}

The materials that were used in this research were blush samples , $\mathrm{HNO}_{3}, \mathrm{H}_{2} \mathrm{O}, \mathrm{HClO}_{4}$, standard solutions of $\mathrm{Pb}\left(\mathrm{NO}_{3}\right)_{2}, \mathrm{Cd}\left(\mathrm{NO}_{3}\right)_{2}$ and $\mathrm{Cr}\left(\mathrm{NO}_{3}\right)_{2}$.

\subsection{Preparation of Standard Solutions}

\subsubsection{0 ppm Pb Standard Solution}

Weigh 1.5985 grams of $\mathrm{Pb}\left(\mathrm{NO}_{3}\right)_{2}$ with $65 \% \mathrm{HNO}_{3}$, then put it in a $1000 \mathrm{~mL}$ measuring flask and dilute it to the limit mark. Then to make a concentration of $50 \mathrm{ppm}$ pipette $5 \mathrm{~mL}$ of the main solution of $1000 \mathrm{ppm} \mathrm{Pb}$ into a $100 \mathrm{~mL}$ measuring flask and diluted with $\mathrm{HNO}_{3} 65 \%$ to the limit mark. To make $10 \mathrm{ppm}$ pipettes $20 \mathrm{~mL}$ of main solution of $50 \mathrm{ppm} \mathrm{Pb}$ into a $100 \mathrm{~mL}$ measuring flask and diluted with $\mathrm{HNO}_{3} 65 \%$ to the limit mark. Preparation of standard solutions then pipette 50, $100,200,300$, and $500 \mu \mathrm{L}$ of the $50 \mathrm{ppm} \mathrm{Pb}\left(\mathrm{NO}_{3}\right)_{2}$ working solution into a $100 \mathrm{~mL}$ measuring flask and diluted with $65 \%$ $\mathrm{HNO}_{3}$ until it has a $\mathrm{Pb}$ concentration of $0,0,2,04,0.8,1,2$, and $1.6 \mathrm{ppm}$ then the absorption was measured at $\lambda 217.0 \mathrm{~nm}$.

\subsubsection{0 ppm Cd Raw Solution}

Weigh 2.583 grams of standard Cd (NO 3 ) 2 powder with $65 \%$ HNO 3 , then put it in a $1000 \mathrm{~mL}$ measuring flask and dilute it to the limit mark. Then to make a concentration of 50 ppm pipette $5 \mathrm{~mL}$ of main solution of $1000 \mathrm{ppm} \mathrm{Cd}$ into a 100 $\mathrm{mL}$ measuring flask and diluted with $\mathrm{HNO} 365 \%$ to the limit mark. To make $10 \mathrm{ppm}$ pipette $20 \mathrm{~mL}$ of main solution of 50 ppm Cd into a $100 \mathrm{~mL}$ measuring flask and diluted with HNO $365 \%$ to the limit mark. Preparation of the standard solution then pipette $5,10,20,30$, and $50 \mu \mathrm{L}$ of the $50 \mathrm{ppm} \mathrm{Cd}$ (NO 3 ) 2 working solution into a $100 \mathrm{~mL}$ measuring flask and diluted with $65 \%$ HNO 3 to a limit mark so that it has a concentration of $\mathrm{Cd} 0,0,02,0.05,0.1,0.2,0.40 .6,0.8$ and 1 ppm then the absorption was measured at $\lambda 228.8 \mathrm{~nm}$.

\subsubsection{0 ppm Cr Raw Solution}

Weigh $3.384 \mathrm{Cr}$ (NO 3 ) 2 with HNO $365 \%$, then put it in a $100 \mathrm{~mL}$ measuring flask and dilute it to the limit mark. Then make $50 \mathrm{ppm}$ pipettes of $50 \mathrm{~mL}$ of $100 \mathrm{ppm} \mathrm{Cr}$ main solution into a $100 \mathrm{~mL}$ measuring flask and dilute with $65 \%$
HNO 3 to the limit mark. To make $10 \mathrm{ppm}$ pipette $20 \mathrm{~mL}$ of main $\mathrm{Cr} 50$ ppm solution into a $100 \mathrm{~mL}$ measuring flask and diluted with HNO $365 \%$ to the limit mark. Preparation of the standard solution then pipette $20 \mathrm{ml}, 40 \mathrm{ml}, 60 \mathrm{ml}$, and $80 \mathrm{ml}$ of $\mathrm{Cr}$ (NO 3 ) 2 working solution in a $100 \mathrm{ml}$ measuring flask diluted with $\mathrm{HNO} 365 \%$ to the limit mark so that it has a $\mathrm{Cr}$ concentration of $0,0.1,0,2,0.40 .8$ and $1.2 \mathrm{ppm}$ then the absorption was measured at $\lambda 357.9 \mathrm{~nm}$.

\subsection{Sample Preparation}

The method that was used was wet digestion. Destruction begins by weighing the blush sample of 1,5 gram tube digestion, then add $25 \mathrm{ml}$ of HNO 3 concentrated. It is the most effective acid and most commonly used in the destruction of wet because it can break the sample into a compound that is biodegradable and a solution of concentrated nitric acid alone volatile, then let stand in an acid room for one night and boil slowly for 35 minutes at a temperature of $830 \mathrm{C}$ to remove all compounds that are easily oxidized then cool the solution and add $10 \mathrm{~mL}$ of $\mathrm{HClO} 4$ $72 \%$, boil slowly until the solution looks colorless ( do not boil the solution until it is dry), cool it down then add $25 \mathrm{~mL}$ $\mathrm{H} 2 \mathrm{O}$ then boil again until all the NO 2 gas comes out, cool then filtered using Whatman N0.40 filter paper and put into a $50 \mathrm{~mL}$ volumetric flask, dilute it to the mark, then homogeneous and the solution is ready to test then the wet digestion results can be analyzed in the Spectrophotometry tool Atomic alloy for analysis of heavy metals $\mathrm{Pb}, \mathrm{Cd}$, and $\mathrm{Cr}$.

\subsection{Determination of Heavy Metal Content}

Heavy metal content of each sample is calculated by heavy metal content with the regression equation of the calibration curve using the formula:

Heavy Metal Content

$$
(\mu \mathrm{g} / \mathrm{g})=\frac{\mathrm{C}(\mu \mathrm{g} / \mathrm{ml})}{\mathrm{B}(\mathrm{g})} \times \mathrm{F}(\mathrm{ml})
$$

\section{RESULTS AND DISCUSSION}

\subsection{Data Collection of Blush On Brands Sold Online in Tangerang City}

The selection of blush samples that are sold online in Tangerang City is to choose a reddish pink color at a price of 18,000 . The total number of test samples was 5 test samples with reddish pink color. There are 2 BPOM registered, and 3 which are not BPOM registered. Then to take the test sample using purposive sampling method. The results of blush on brands that are sold online in Tangerang City are shown in Table 1: 
Table 1. Data collection results for blush on brands that are sold online in Tangerang City

\begin{tabular}{llll}
\hline No. & Brand & \multicolumn{2}{l}{ The amount of blush } \\
\cline { 3 - 4 } & & Registered & Not registered \\
\hline 1 & MG & $\sqrt{ }$ & \\
2 & LML & & $\mathrm{X}$ \\
3 & FLE & & $\mathrm{X}$ \\
4 & VV & $\sqrt{ }$ & \\
5 & BQ & & $\mathrm{X}$ \\
\hline
\end{tabular}

\subsection{Determination of levels of Lead, cadmium and chromium contamination in several blush on brands}

This identification is done by doing sample preparation. Sample preparation in this study was carried out using the wet digestion method, namely through the addition of a strong acid solution. The strong acid solution used was aqua regia ( $\mathrm{HCl}: \mathrm{HNO} 3=3: 1)$. According to Van Loon (1980), aqua regia has the ability to dissolve metals in a faster process than a single strong acid. Furthermore, the heavy metal sample was analyzed quantitatively using the Atomic Absorption Spectrophotometer (AAS).

Based on the test results using Atomic Absorption Spectrophotometer (AAS), it can be seen the identification results of the presence of heavy metal content of $\mathrm{Pb}, \mathrm{Cd}$ and $\mathrm{Cr}$ in the blush on samples, whether they have a BPOM registration number or not. The results of this quantitative analysis are shown in Table 2, 3 and 4 below:

Table 2. Metal Data Processing Pb

\begin{tabular}{|c|c|c|c|c|}
\hline \multirow[t]{2}{*}{ Sample } & \multicolumn{2}{|c|}{ Sample concentration $(\mathrm{mg} / \mathrm{L})$} & \multirow{2}{*}{$\begin{array}{l}\text { Average a true concentration } \\
\qquad(\mathrm{mg} / \mathrm{kg})\end{array}$} & \multirow{2}{*}{$\begin{array}{c}\text { Maximum level (mg / } \\
\mathbf{k g})\end{array}$} \\
\hline & 1 & 2 & & \\
\hline $\mathrm{MG}$ & -0.0972 & -0.0813 & Sgd & \\
\hline LML & -0.086 & -0.0767 & Sgd & $\leq 20$ \\
\hline VV & -0.1097 & -0.1036 & Sgd & (BPOM) \\
\hline FLE & -0.0988 & -0.1079 & Sgd & \\
\hline BQ & -0.0784 & -0.0604 & Sgd & \\
\hline
\end{tabular}

NOTE :

$\mathrm{Pb}$, Abs: Measured absorbance

$\mathrm{Pb}$, Conc: Measured concentration ( $\mathrm{mg} / \mathrm{L}$ )

Signed: Not detected (below the detection limit value $<0.4(\mathrm{mg} / \mathrm{kg}$ ) 
Table 3. Metal Data Processing Cd

\begin{tabular}{|c|c|c|c|c|}
\hline \multirow[t]{2}{*}{ Sample } & \multicolumn{2}{|c|}{ Sample concentration $(\mathrm{mg} / \mathrm{L})$} & \multirow{2}{*}{$\begin{array}{c}\text { Average a true } \\
\text { concentration }(\mathrm{mg} / \mathrm{kg})\end{array}$} & \multirow{2}{*}{$\begin{array}{c}\text { Maximum level } \\
\text { (mg / kg) }\end{array}$} \\
\hline & 1 & 2 & & \\
\hline $\mathrm{MG}$ & -0.0159 & -0.0158 & Sgd & $\leq 5$ \\
\hline LML & -0.0143 & -0.0151 & Sgd & (BPOM) \\
\hline VV & -0.0155 & -0.0164 & Sgd & \\
\hline FLE & -0.0163 & -0.0172 & Sgd & \\
\hline BQ & -0.0145 & -0.0159 & Sgd & \\
\hline
\end{tabular}

NOTE :

Cd, Abs: Measured absorbance

Cd, Conc: Measured concentration ( $\mathrm{mg} / \mathrm{L}$ )

Signed: Not detected (below the detection limit value $<0.1(\mathrm{mg} / \mathrm{kg})$

Table 4. Metal Data Processing Cr

\begin{tabular}{|c|c|c|c|c|}
\hline \multirow[t]{2}{*}{ Sample } & \multicolumn{2}{|c|}{ Sample concentration $(\mathrm{mg} / \mathrm{L})$} & \multirow{2}{*}{$\begin{array}{c}\text { Average a true concentration } \\
(\mathrm{mg} / \mathrm{kg})\end{array}$} & \multirow{2}{*}{$\begin{array}{c}\text { Maximum level } \\
(\mathrm{mg} / \mathrm{kg})\end{array}$} \\
\hline & 1 & 2 & & \\
\hline $\mathrm{MG}$ & -0.118 & -0.1511 & Sgd & Nigeria $9.81 \mu \mathrm{g} / \mathrm{g}$ \\
\hline LML & -0.0885 & -0.1791 & Sgd & and USA $15.09 \mu \mathrm{g} /$ \\
\hline VV & 0.0542 & 0.054 & 1.8 & $\mathrm{~g}$ \\
\hline FLE & -0.1415 & -0.0372 & Sgd & \\
\hline BQ & -0.1462 & -0.1501 & Sgd & \\
\hline
\end{tabular}

\section{NOTE :}

Cr, Abs: Measured absorbance

$\mathrm{Cr}$, Conc : Measured concentration $(\mathrm{mg} / \mathrm{L})$

Signed : Not detected (below the detection limit value $<0.2(\mathrm{mg} / \mathrm{kg})$

The identification results show that the $\mathrm{Pb}$ metal, $\mathrm{Cd}$ on Blush on which has a BPOM registration number and is not registered with BPOM have negative results, these results are still below the safe limit set by BPOM RI Number HK.03.1.23.07.11.6662 of 2011, which is $20 \mathrm{mg} / \mathrm{kg}$ for $\mathrm{Pb}$, at $\mathrm{Cd}$ of $5 \mathrm{mg} / \mathrm{kg}$. Meanwhile, for the $\mathrm{Cr}$ metal in $\mathrm{VV}$ samples that had BPOM registration, the results were $1.8 \mathrm{mg}$ $/ \mathrm{kg}$. The level of $\mathrm{Cr}$ in this study was still below the threshold that referred to Nigeria $9.81 \mu \mathrm{g} / \mathrm{g}$ and USA $15.09 \mu \mathrm{g} / \mathrm{g}$. Meanwhile, the other samples were not identified to contain $\mathrm{Cr}$ metal. This is probably due to the very small concentrate on or even the absence of metal contaminants in the sample, causing the test reagent to bind to the metal so little that the results obtained are less visible. Thus, all samples were still within safe limits against contamination of heavy metals $\mathrm{Pb}$, $\mathrm{Cd}$ and $\mathrm{Cr}$.

Lead $(\mathrm{Pb})$ in cosmetic products can come from several natural ingredients that contain lead $(\mathrm{Pb})$ such as dyes and pigments or tools that were used during the production process (Sharafi et al., 2015). Lead $(\mathrm{Pb})$ can enter through penetration into the membranes or skin, absorption through the skin can occur due to lead can dissolve in oil or fat (Palar, 2012).

According to (Godt et al. 2006) cadmium (Cd) is purified and consumed for use in cosmetic products because it is a colored pigment. Chronic exposure to cadmium induces toxicity in kidney and skin tumors. While chromium $(\mathrm{Cr})$ is present as an impurity (Corraz, et al, 2009). By moist skin, heavy metals can be absorbed through skin contact (Omolaoye, et al, 2010).

Research conducted by Supriyadi in 2008 showed that both domestic and foreign product lipsticks contained $\mathrm{Pb}$ and $\mathrm{Cd}$ metals, with $\mathrm{Pb}$ and $\mathrm{Cd}$ levels of 33.61 and $3.41 \mathrm{mg} / \mathrm{kg}$ (domestic products) and 63.34 and $2.97 \mathrm{mg} / \mathrm{kg}$ (foreign products). Thus, it can be assumed that both domestic and foreign lipstick cosmetic products may contain $\mathrm{Pb}$ and $\mathrm{Cd}$.

\section{CONCLUSION}

The blush on sample analyzed using the Atomic Absorption Spectrophotometry method does not contain heavy metal such as $\mathrm{Pb}, \mathrm{Cd}$, there was only one sample of the VV brand that was read contained $\mathrm{Cr}$ metal.

Based on the results shown that the VV sample Cr metal has BPOM registration giving results with a level of 1.8 $\mathrm{mg} / \mathrm{kg}$. The level of $\mathrm{Cr}$ in this study was still below the threshold that referred to Nigeria $9.81 \mu \mathrm{g} / \mathrm{g}$ and USA 15.09 $\mu \mathrm{g} / \mathrm{g}$. 


\section{ACKNOWLEDGMENT}

This work was supported by the Muhammadiyah Pharmacy College in Tangerang.

\section{REFERENCES}

[1] Andayani R., Rahma S. Y., Martinus. (2018). Analisis Logam Kromium (Cr) Pada Sediaan Perona Pipi (Blush On). Jurnal Sains Farmasi dan Klinik, Vol 5(3).

[2] Ardyanto, Denny. (2005). Deteksi Pencemaran Timah Hitam $(\mathrm{Pb})$ dalam Darah Masyarakat yang Terpajan Timbal (plumbum). Jurnal Kesehatan Lingkungan, 2(1): 67-76.

[3] Barros A. I., Silva T. V., Ferreira E. C., Gomes Neto J. A.(2015). Determination of lead in eye shadow and blush by high resolution continuum source graphite furnace atomic absorption spectrometry employing direct solid sampling. J.Braz. Chem. Soc., 26:140- 146.

[4] Batista, É. F., Augusto, A. dos S., Pereira- Filho, E. R. (2016). Chemometric evaluation of $\mathrm{Cd}, \mathrm{Co}, \mathrm{Cr}, \mathrm{Cu}, \mathrm{Ni}$ (inductively coupled plasma optical emission spectrometry) and $\mathrm{Pb}$ (graphite furnace atomic absorption spectrometry) concentrations in lipstick samples intended to be used by adults and children. Talanta,Vol. 150: 206-212.

[5] BPOM. (2014). Peraturan Kepala Badan Pengawas Obat dan Makanan Republik Indonesia Nomor 17 Tahun 2014 tentang Perubahan Atas Peraturan Kepala Badan Pengawas Obat dan Makanan Nomor HK.03.1.23.07.11.6662 Tahun 2011 tentang Persyaratan Cemaran Mikroba dan Logam Berat dalam Kosmetika. Jakarta: BPOM.

[6] Bocca, B., Pino A., Alimonti A., Forte, G.(2014).Toxic metals contained in cosmetics: A status report.Regulatory Toxicology and Pharmacology, 68: 447- 467.

[7] Djamilah Arifiyana dan MA. Hanny Ferry Fernanda. 2018. Analisis Kualitatif Dan Kuantitatif Cemaran Logam Berat Timbal $(\mathrm{Pb})$ Dan Kadmium (Cd) Pada Produk Kosmetik Pensil Alis Menggunakanspektrofotometer Serapan Atom (Ssa). Journal of Research and Technology.

[8] Forte G., Petrucci F., Bocca B.(2008). Metal allergens of growing significance: epidemiology, immunotoxicology, strategies for testing and prevention, Inflamm. Allergy Drug Targets, 7: 1-18.

[9] Godt, J., F. Scheidig, C. Grosse-Siestrup, V. Esche, P. Brandenburg, A. Reich, and DA Groneberg. 2006. The toxicity of cadmium and resulting hazards for human health. Journal.

[10] Hepp, Nancy, M., William, R., Mindak, John, Cheng. (2009). Determination of Total Lead in Lipstick: Development and Validation of a Microwave-Assisted Digestion, Inductively Coupled Plasma- Mass Spectrometric Method.J. Cosmet. Sci, 60 : 405-414.

[11] Jaya, Farida, Guntarti, Kamal. (2013). Penetapan Kadar $\mathrm{Pb}$ pada Shampoo Berbagai Merk dengan Metode Spektofotometri Serapan Atom. Jurnal Pharmaciana. 3(2) : 9-13.
[12] Kusantati, Herni. 2008. Tata Kecantikan Kulit. Jakarta: Direktorat Pembinaan Sekolah Menengah Kejuruan, Direktorat Jenderal Manajemen Pendidikan Dasar dan Menengah, Departemen Pendidikan Nasional Peraturan Kepala Badan Pengawas Obat dan Makanan Republik Indonesia.

[13] New York City Department of Health.(1999).Lead poisoning prevention program. New York: DOH.

[14] Palar, D.H. 2012. Pencemaran dan Toksikologi Logam Berat. PT Rineka Cipta.Jakarta.

[15] Omolaoye, J. A., A. Uzairu, and C. E. Gimba. 2010. Heavy metal assessment of some eye shadow products imported into Nigeria from China. Journal Archives of Applications Sciences 2:76-84.

[16] Sharafi, K., Fattahi, N., Pirsaheb, M., Yarmoharmadi, H. \& Davil, M. F. 2015. Trace Determination of Lead in Lipsticks and Hair Dyes using Microwave-assisted Dispersive Liquid-liquid Microextraction and Graphite Furnace Atomic Absorption Spectrometry. International Journal of Cosmetic Science; 37; 489-495.

[17] Supriyadi. (2008). Analisa Logam Kadmium, Timbal, dan Krom pada Lipstik secara Spektofotometri Serapan Atom.Jurnal Kimia dan Teknologi, 4 : 299-305.

[18] Valet B., Mayor M., Fitoussi F., Capellier R., Dormoy M., Ginestar J. (2007). Colouring agents in cosmetic products (excluding hairdyes): types of decorative cosmetic products, in: A. Salvador, A. Chisvert (Eds.)Analysis of Cosmetic Products, 1: 141-152.

[19] VolpeM.G.,NazzaroM.,CoppolaR.,RapuanoF., AquinoR.P.(2012). Determination and assessmentsofselectedheavymetalsineyesh adowcosmeticsfrom China, ItalyandUSA. MicrochemJournal, 101: 65-69.

[20] Van Loon, J.C. (1980). Analytical Atomic Absorption Spectroscopy Selected Methods. New York: Academic Press 